\title{
Reflecting on compliance with Broad-Based Black Economic Empowerment codes of good practice: Trends and suggestions
}

\begin{tabular}{|c|c|}
\hline \multicolumn{2}{|c|}{$\begin{array}{l}\text { Authors: } \\
\text { Jan A. Dreyer }{ }^{1} \text { (D) } \\
\text { Suzette Viviers }{ }^{2} \\
\text { Nadia Mans-Kemp }\end{array}$} \\
\hline $\begin{array}{l}\text { Affiliations: } \\
{ }^{1} \text { School of Acc } \\
\text { Faculty of Eco } \\
\text { Management } \\
\text { Stellenbosch } \\
\text { Stellenbosch, }\end{array}$ & $\begin{array}{l}\text { ountancy, } \\
\text { nomic and } \\
\text { Sciences, } \\
\text { Jniversity, } \\
\text { South Africa }\end{array}$ \\
\hline $\begin{array}{l}{ }^{2} \text { Department } \\
\text { Management, } \\
\text { Economic and } \\
\text { Sciences, Stell } \\
\text { University, Ste } \\
\text { South Africa }\end{array}$ & $\begin{array}{l}\text { f Business, } \\
\text { Faculty of } \\
\text { Management } \\
\text { enbosch } \\
\text { Ilenbosch, }\end{array}$ \\
\hline $\begin{array}{l}\text { Correspondin } \\
\text { Jan Dreyer, } \\
\text { jdreyer@sun.a }\end{array}$ & $\begin{array}{l}\text { g author: } \\
\text { c.za }\end{array}$ \\
\hline $\begin{array}{l}\text { Dates: } \\
\text { Received: } 13 \mathrm{~F} \\
\text { Accepted: } 10 \\
\text { Published: } 30\end{array}$ & $\begin{array}{l}\text { eb. } 2020 \\
\text { Mec. } 2020 \\
\text { Mar. } 2021\end{array}$ \\
\hline $\begin{array}{l}\text { How to cite th } \\
\text { Dreyer, J.A., Vi } \\
\text { Mans-Kemp, } \\
\text { Reflecting on } \\
\text { with Broad-Ba } \\
\text { Economic Emp } \\
\text { codes of good } \\
\text { Trends and su } \\
\text { South African } \\
\text { Business Man } \\
\text { a1963. https:/ } \\
\text { org/10.4102/s } \\
\text { v52i1.1963 }\end{array}$ & $\begin{array}{l}\text { is article: } \\
\text { viers, S., \& } \\
\text { J. (2021). } \\
\text { compliance } \\
\text { sed Black } \\
\text { oowerment } \\
\text { practice: } \\
\text { ggestions. } \\
\text { Journal of } \\
\text { agement, 52(1), } \\
\text { /doi. } \\
\text { ajbm. }\end{array}$ \\
\hline $\begin{array}{l}\text { Copyright: } \\
\text { (C) 2021. The A } \\
\text { Licensee: AOS } \\
\text { is licensed und } \\
\text { Creative Comn } \\
\text { Attribution Lic }\end{array}$ & $\begin{array}{l}\text { uthors. } \\
\text { IS. This work } \\
\text { ler the } \\
\text { nons } \\
\text { ense. }\end{array}$ \\
\hline Read online: & \\
\hline 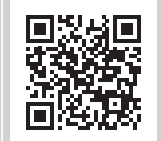 & $\begin{array}{l}\text { Scan this QR } \\
\text { code with your } \\
\text { smart phone or } \\
\text { mobile device } \\
\text { to read online. }\end{array}$ \\
\hline
\end{tabular}

Purpose: Broad-Based Black Economic Empowerment (B-BBEE) legislation was introduced to promote the economic participation of black people in the South African economy. Some scholars have argued that, whilst it is important to empower black people, B-BBEE legislation is not necessarily the best mechanism available. Despite the criticism against B-BBEE, it remains the most prominent means of uplifting black people in the country. This study was conducted to reflect on whether selected companies listed on the Johannesburg Stock Exchange have improved their B-BBEE compliance and determine which elements included in the 2004 and 2007 Codes of Good Practice the companies have focussed on. The authors highlight progress made by listed companies in empowering black people and offer suggestions for improvement.

Design/methodology/approach: A comprehensive data set, comprising 1767 observations for 379 listed companies over more than a decade (2004-2015), was analysed. Mixed-model analysis of variance and Fisher's least significant difference tests were used to assess the significance of the observed trends. Significant increases in B-BBEE scores (in total and per element) were observed.

Findings/results: The mean socio-economic development B-BBEE element score showed the largest change over the study period, whilst the employment equity element reflected the smallest change.

Practical implications: The Department of Trade and Industry should reflect on the attainability of certain targets, especially employment equity and ownership. Government and listed companies are encouraged to critically evaluate the optimal manner to empower previously disadvantaged individuals.

Originality/value: This study comprehensively explores the trends in B-BBEE compliance using statistical methods to provide suggestions to the Department of Trade and Industry and companies listed on the JSE.

Keywords: Broad-Based Black Economic Empowerment; South Africa; socio-economic development; management control; compliance.

\section{Introduction and motivation for the study}

After the first democratic election in South Africa, government emphasised the importance of introducing mechanisms to rectify the evident social and economic inequalities (Acemoglu, Gelb, \& Robinson, 2007). The introduction of the Broad-Based Black Economic Empowerment (B-BBEE) policy was deemed to be essential to promote the participation of black individuals in the local economy (Sartorius \& Botha, 2008). Whilst certain researchers are critical about the true beneficiaries of B-BBEE and question whether legislation is truly achieving the stated aims (Hoffman, 2008; Patel \& Graham, 2012), the moral imperative of uplifting the poor in the country is not debatable (Mathura, 2009; Morris, 2018).

The term B-BBEE was formally introduced in the legislative framework of South Africa in 2003 with the implementation of the Broad-Based Black Economic Empowerment Act (No. 53 of 2003) (Department of Trade and Industry [DTI], 2003). The following definition was incorporated in the act (DTI, 2003):

$[B]$-BBEE means the empowerment of all black people including women, workers, youth, people with disabilities and people living in rural areas through diverse but integrated socio-economic strategies that include, but are not limited to increasing the number of black people that manage, own and 
control enterprises and productive assets; facilitating ownership and management of enterprises and productive assets by communities, workers, cooperatives and other collective enterprises; human resource and skills development; achieving equitable representation in all occupational categories and levels in the workforce; preferential procurement and investment in enterprises that are owned or managed by black people. (p. 4)

Black people include African, Indian, mixed race and Chinese individuals (DTI, 2003).

Based on the definition, it is evident that the purpose of the 2003 Act was the redistribution of wealth to those disadvantaged by the apartheid regime pre-1994. Companies are encouraged to participate in B-BBEE, as it is designed to empower black people, especially those wishing to conduct business with government institutions. The 2003 Act did not provide guidelines on the measurement of B-BBEE, but rather specified that the Codes of Good Practice should stipulate how B-BBEE would be measured. As such, the 2003 Act was followed by the release of the Codes of Good Practice in 2004 and 2007.

A revised B-BBEE Act was published in 2013, accompanied by revised Codes of Good Practice (DTI, 2013). Companies' compliance with B-BBEE is measured against the applicable Codes and presented as a score. Based on these scores, comparative compliance levels are computed for listed companies (DTI, 2007). The Codes define the elements (including ownership, management control, employment equity, skills development, preferential procurement and enterprise development) that are utilised in determining the total B-BBEE score for qualifying companies. The scores for the respective elements should be verified by a registered B-BBEE auditor, which then provides the company with an official B-BBEE certificate. This certificate could be used for government tenders and to obtain new clients.

Broad-Based Black Economic Empowerment could arguably be regarded as a barrier for foreign investment. A relaxation of these requirements has been requested by the European Union (Gules, 2018) to encourage companies to invest in South Africa. Some researchers and role players furthermore expressed the opinion that the design of B-BBEE (as stipulated in the B-BBEE Act of 2003 and 2013) is not ideal and that it should be replaced by another intervention that would better reach the goal of uplifting previously disadvantaged South Africans (Institute of Race Relations [IRR], 2012; Ngwenya, 2019). This sentiment is also echoed by the minister of trade and industry in South Africa (Phakathi, 2019). Although Andrews (2008) argued that B-BBEE can be effective in reducing poverty amongst black people, the impact of B-BBEE on poverty eradication has not yet translated in greater income equality in the country (IRR, 2017). The opposite is true, in that the inequality (measured by the Gini-coefficient) increased since the 1990s (The World Bank, 2019).
Proponents of B-BBEE argue that poverty amongst black people is persistent because of a lack of B-BBEE compliance (Mathura, 2009; Morris, 2018). The critics and proponents of B-BBEE can, perhaps, both be right in that B-BBEE can be more effective if $\mathrm{B}-\mathrm{BBEE}$ is reformed to enhance the promotion of equality. It can, however, not be dismissed that B-BBEE remains the most prominent direct government policy to empower black people (Mathura, 2009; Morris, 2018). As such, it is important to understand how companies comply with B-BBEE and which elements companies tend to focus on.

Previous authors focussed on the beneficiaries of B-BBEE (Hoffman, 2008; Patel \& Graham, 2012). Others explored the relationship between B-BBEE scores and share market performance (Chipeta \& Vokwana, 2011; De Villiers \& Ferreira, 2011; Jackson, Allesandri, \& Black, 2005; Mehta \& Ward, 2017; Strydom, Christison, \& Matias, 2009; Van der Merwe \& Ferreira, 2014; Ward \& Muller, 2010; Wolmarans \& Sartorius, 2009) and other financial performance measures (Acemoglu et al., 2007; Kleynhans \& Kruger, 2014; Mathura, 2009; Morris, 2018). As far as it could be established, no authors empirically investigated trends in B-BBEE compliance by accounting for changes in the total B-BBEE and element scores.

Although B-BBEE remains a key consideration in South Africa, there is controversy pertaining to whether the current legislation and accompanying codes have resulted in considerable changes in corporate policies and practices. This study was hence conducted to reflect on whether 379 companies listed on the Johannesburg Stock Exchange (JSE) have improved their B-BBEE compliance and to determine which elements included in the Codes of Good Practice the companies focussed on over the period 2004-2015.

Corporate leaders could arguably, consciously or subconsciously, engage in impression management practices to influence the perceptions of stakeholders, including government and society at large, about their companies' B-BBEE endeavours. Bolino and Turnley (1999) applied Jones and Pittman's (1982) five self-promotional styles to develop an impression management scale. In the context of B-BBEE compliance, companies could arguably focus on self-promotion (to be viewed as competent-empowered companies) and exemplification (to be seen as morally exemplary based on their empowerment initiatives). Companies could also comply with B-BBEE as a means of achieving social justice (and corporate social responsibility). Focus could accordingly be placed on those B-BBEE requirements that are 'easier' to comply with to enhance stakeholders' impressions of the company. The findings shed light on which elements received considerable and limited corporate attention, respectively.

A brief history of B-BBEE will now be provided. Thereafter, the Codes of Good Practices (of 2004, 2007 and 2013) will be introduced, followed by the research design and methodology adopted in this study. The empirical evidence will then be presented followed by conclusions and recommendations. 


\section{Initiatives to transform the post- apartheid South African economy}

Economic transformation in South Africa started before the end of apartheid in April 1994 (Ponte, Roberts, \& Van Sittert, 2007). In the 1980s, some businesses rearranged their ownership structures to create a black middle class with interest in the local economy to enhance economic and political stability (Engdahl \& Hauki, 2001; Ponte et al., 2007). Former president Thabo Mbeki highlighted the importance of economic transformation in his so-called 'Two Nations' speech in 1998 by stating that reconciliation and national unity are unachievable dreams in the absence of economic transformation (Ponte et al., 2007).

As a result of this drive for economic transformation, the African National Congress (ANC) launched the so-called Reconstruction and Development Program (RDP) (Habib \& Padayachee, 2000). This socio-economic policy framework had five interrelated sections dealing with social needs, development of human resources, building the economy, democratising the society and state and implementing the RDP (Habib \& Padayachee, 2000). The programme focussed on the transfer of share ownership. As such, the RDP was criticised for not boosting business confidence or encouraging foreign investment (Habib \& Padayachee, 2000; Ponte et al., 2007).

The ANC altered and formalised the RDP, resulting in the publication of an economic framework called Growth, Employment and Redistribution (GEAR) in 1996 (Ponte et al., 2007). In effect, GEAR led to empowerment deals where large white-owned conglomerates sold shares to black people, even though the majority of the beneficiaries were politically connected individuals (Ntim \& Soobaroyen, 2013; Tangri \& Southall, 2008).

The end of the millennium signalled the end of the first phase of black economic transformation in the country. As a result of growing calls for transformation to be more inclusive and to cover more aspects of socio-economic development than just the transfer of ownership, the second phase of economic transformation, called Black Economic Empowerment (BEE), was launched and the BEE Commission was formed in 1998 (Ponte et al., 2007). With the release of this commission's report in 2001, the government acknowledged the need to broaden the nature of BEE. As such, BEE had to incorporate the requirements of affirmative action and focus on human resource development, enterprise development, preferential procurement, corporate social investment activities and ownership (Acemoglu et al., 2007; Ponte et al., 2007). It was at this stage that the term B-BBEE was introduced (Acemoglu et al., 2007).

Broad-Based Black Economic Empowerment requirements apply to all commercial and government institutions (DTI, 2003). The BEE Commission (2001) recommended that there should be a co-ordinating council to oversee the implementation of B-BBEE. As a result, the B-BBEE Advisory Council was established to implement B-BBEE legislation and offer advice to the government on B-BBEE-related issues. This council is responsible for determining the strategic direction for B-BBEE, which is then translated into the Codes of Good Practice by the minister of trade and industry. The Codes offer guidelines on how B-BBEE should be practically implemented and measured. Should the Codes not achieve their purpose of successfully rectifying the inequalities of the past, government can alter the Codes again in future (RSA Presidency, 2015).

According to Gules (2018), an 'expiry date' for B-BBEE is necessary as B-BBEE regulations are seen as a barrier for foreign investment. Acemoglu et al. (2007) predicted that B-BBEE will reach a third phase. Recall that the first phase was unstructured BEE until the end of 1999. The second phase was formalised, structured B-BBEE with the release of the BEE Commission report and the implementation of the 2003 Act and revised in 2013. The third phase of B-BBEE will arguably occur when the economic imbalances have been corrected and companies and individuals can compete on equal footing (Acemoglu et al., 2007). Once this proposed third phase has been reached, the current B-BBEE legislation is likely to be redundant.

\section{Overview of the Codes of Good Practice}

The 2003 and 2013 B-BBEE Acts set out the principles of B-BBEE, whereas specific empowerment practices are explained in the Codes of Good Practice (DTI, 2003, 2007, 2013). It is, therefore, important to consider the Codes to understand the practical implications of B-BBEE for companies in South Africa.

\section{The 2004 and 2007 Codes of Good Practice}

The DTI issued the first draft of the Codes of Good Practice in 2004. These codes aimed to adopt a 'balanced approach', which was measured by a generic scorecard (DTI, 2004). The 2004 Codes stated that there are three main components of B-BBEE, namely direct empowerment, human resource development and indirect empowerment. Direct empowerment relates to equity transfers and appointing black individuals in management positions. Human resource development comprises employment equity and skills development. Indirect empowerment refers to a company's interaction with the community. Purchases from preferential suppliers (buying from suppliers with a high B-BBEE score), enterprise development (by assisting black entrepreneurs) and corporate social investment activities are related to the last component (DTI, 2004).

The 2004 Codes included seven key elements, namely ownership, management control, employment equity, skills development, preferential procurement, enterprise development and a residual factor (DTI, 2004). Ownership referred to the voting rights and economic interests associated with equity holding. Management control entailed that black members of an organisation have the power to 
determine policies and provide direction to economic activities and resources. Management control comprised the percentage of black board members and the proportion of executives or senior managers. The target set out in the COGP is $40 \%$ weighted in terms of whether the employee is female (50\% higher score) or in an executive authority (such as $\mathrm{CFO}, \mathrm{CEO}$, etc.). Employment equity focussed on the promotion of equal opportunity and fair treatment of employees. Companies are expected to invest in the development of black workers' skills (DTI, 2004).

Preferential procurement, enterprise development and the residual factor related to indirect empowerment (DTI, 2004). Preferential procurement dealt with the percentage of purchases made from B-BBEE compliant suppliers. This element is of specific relevance to companies that compete for government contracts. Enterprise development related to funding and / or supporting black entrepreneurs. The residual factor related to social investment in activities relevant to an entity's environment (business environment, sector and geographical environment) (DTI, 2004).

The B-BBEE Advisory Council refined the draft Codes in 2007. The content of the 2004 and 2007 Codes remained largely the same. A major clarification dealt with how small enterprises should be evaluated. Small companies (in terms of turnover) were exempt from applying B-BBEE and could be awarded a level four contributor status (DTI, 2007). A qualifying small enterprise (turnover between R5 million and R35 million) only needed to focus on four of the seven elements. The residual factor was clarified as the 'socio economic development and sector-specific contributions element'. Minimal changes were made to the weightings of certain elements (employment equity, skills development, employment equity and socio-economic development) (DTI, 2004).

The most significant clarification entailed redefining of the different levels of contributors (DTI, 2007). The 2007 Codes made provision for nine levels (level one to eight contributors plus a level for non-compliant contributor status). Companies could achieve a score of more than 100 points based on the allocation of seven possible bonus points (DTI, 2007; Werksmans, 2014).

\section{The 2013 Codes of Good Practice}

The percentage of black income in comparison with white income did not change considerably since the implementation of B-BBEE in 2003 (IRR, 2009). The B-BBEE Commission therefore adjusted the 2007 Codes to urge businesses to become more compliant. The revised Codes were released in October 2013 and the effective implementation date was May 2015. Companies' compliance levels could decrease by two levels if they did not increase their B-BBEE score in line with the 2013 Codes (Empowerdex, 2016). A comparison of the 2013 Codes relative to the 2007 Codes (Tables 1 and 2) shows that certain B-BBEE elements had been grouped together. The weightings of the elements in terms of the number of points allocated were also amended (Table 2).

The targets for management control, preferential procurement and socio-economic development increased from the 2007 to

TABLE 1: Compliance targets for Broad-Based Black Economic Empowerment scores under the 2007 and 2013 Codes.

\begin{tabular}{llll}
\hline Codes & Element & Target & Measured element \\
\hline 2007 & Ownership (\%) & $25+1$ vote & Total ordinary shares \\
& Management control (\%) & $40-50$ & Top management and directors \\
& Employment equity (\%) & $43-68$ & Junior to senior management \\
& Skills development (\%) & 3 & Total payroll spend \\
& Preferential procurement (\%) & $50-70$ & Total expenditure \\
& Enterprise development (\%) & 3 & Net profit after tax \\
& Socio-economic development (\%) & 1 & Net profit after tax \\
& Ownership (\%) & Total shares \\
& Management control (\%) & $25+1$ vote & Management and staff demographic composition \\
& Skills development (\%) & $50-88$ & Total payroll spend \\
& Supplier development (\%) & 6 & Total measured procurement spend \\
& & Preferential procurement: 80 & Net profit after tax \\
& Socio-economic development (\%) & Supplier development: 2 & Net profit after tax \\
\hline
\end{tabular}

Source: Department of Trade and Industry (DTI). (2007). Codes of good practice. Retrieved from https://www.thedti.gov.za/economic_empowerment/docs/Inside.pdf; Department of Trade and Industry (DTI). (2013). Codes of good practice. Retrieved from https://www.thedti.gov.za/business_regulation/acts/BEE-Amendment_ACT2013.pdf

TABLE 2: Comparison of the 2007 and 2013 Codes (points allocated per element).

\begin{tabular}{lll}
\hline Element & 2017 pionts & 2013 points \\
\hline Ownership & 20 plus 3 bonus points & 25 \\
Management control & - Management control -10 plus 1 bonus point. & 15 plus 4 bonus points \\
Skills development & 15 & 20 plus 5 bonus points \\
Supplier development & - Preferential procurement -20 & 40 plus 4 bonus points \\
Socio-economic development & 5 & 5 \\
Total available & 107 & 118 \\
\hline
\end{tabular}

Source: Werksmans. (2014). Amendments to the B-BBEE Act and the codes explained. Retrieved from http://www.werksmans.com/wpcontent/uploads/2014/02/040002WERKSMANS-bbbeebooklet.pdf 
the 2013 Codes (Table 1). As shown in Table 2, companies could achieve bonus points that allow them to achieve a score of more than 105 points (2013 Codes). Bonus points could be acquired for achieving specific targets. The bonus points could 'ease the compliance pressure', should a company meet certain criteria. The targets for the respective elements can be considered stringent (De Wet, 2016). None of the targets have been lowered since 2007.

Sub-minimum requirements apply for ownership, skills development and enterprise and supplier development. At least $40 \%$ of the targets should be obtained by all large companies (with a turnover of more than R50 million) for these priority elements (DTI, 2013). Should a company not achieve $40 \%$ of these targets, it will be awarded a noncompliant status (DTI, 2013). A comparison between the scores required to qualify for various compliance levels under the 2007 and 2013 Codes is provided in Table 3.

It is evident from Table 3 that companies could have expected a decrease in their compliance levels when the 2013 Codes became effective. Although compliance is encouraged for all companies, it is only compulsory for government institutions to comply with B-BBEE (DTI, 2013). However, companies that aim to conduct business with government will have to prove that they comply with B-BBEE requirements. In turn, such companies are likely to expect that their suppliers should also comply with B-BBEE (because of the preferential procurement element). More empowered companies are likely to have a higher success rate in receiving government contracts and contracts with those wanting to do business with government, resulting in a competitive advantage.

As explained in the introduction, previous authors focussed on change in share price and certain financial performance measures but did not account for trends in the element scores. Controversy pertaining to whether B-BBEE legislation meets its stated objectives was also explained. By accounting for companies' compliance with the 2004 and 2007 versions of the Codes of Good Practice, positive compliance trends and scope for improvement can be highlighted. It is expected that the changes in the Codes of Good Practice would encourage companies to give

TABLE 3: Broad-Based Black Economic Empowerment compliance levels (2007 vs. 2013).

\begin{tabular}{lcc}
\hline B-BBEE status & \multicolumn{2}{c}{ Codes } \\
\cline { 2 - 3 } & 2007 & 2013 \\
\hline Level one contributor & $\geq 100$ points & $\geq 100$ points \\
Level two contributor & 85 , but $<100$ points & $\geq 95$, but $<100$ points \\
Level three contributor & $\geq 75$, but $<85$ points & $\geq 90$, but $<95$ points \\
Level four contributor & $\geq 65$, but $<75$ points & $\geq 80$, but $<90$ points \\
Level five contributor & $\geq 55$, but $<65$ points & $\geq 75$, but $<80$ points \\
Level six contributor & $\geq 45$, but $<55$ points & $\geq 70$, but $<75$ points \\
Level seven contributor & $\geq 40$, but $<45$ points & $\geq 55$, but $<70$ points \\
Level eight contributor & $\geq 30$, but $<40$ points & $\geq 40$, but $<55$ points \\
Non-compliant contributor & $<30$ points & $<40$ points \\
\hline
\end{tabular}

Source: Department of Trade and Industry (DTI). (2007). Codes of good practice. Retrieved from https://www.thedti.gov.za/economic empowerment/docs/Inside.pdf; Department of . gov.za/business_regulation/acts/BEE-Amendment_ACT2013.pdf

B-BBEE, Broad-Based Black Economic Empowerment. more attention to their B-BBEE policies and practices. The authors hence assessed whether a sample of JSE-listed companies has managed to improve its B-BBEE compliance by accounting for total and per element B-BBEE scores over the period 2004-2015. The following hypotheses were formulated:

$\mathbf{H}_{\mathbf{A}, \mathbf{1}}$ : The total B-BBEE scores of the considered JSE-listed companies improved over the period 2004-2015.

$\mathbf{H}_{\mathbf{A}, 2}$ : The B-BBEE ownership element scores of the considered JSE-listed companies improved over the period 2004-2015.

$\mathbf{H}_{\mathrm{A}, 3}$ : The B-BBEE management control element scores of the considered JSE-listed companies improved over the period 2004-2015.

$\mathbf{H}_{\mathrm{A}, 4}$ : The B-BBEE employment equity element scores of the considered JSE-listed companies improved over the period 2004-2015.

$\mathbf{H}_{\mathrm{A}, 5}$ : The B-BBEE skills development element scores of the considered JSE-listed companies improved over the period 2004-2015.

$\mathbf{H}_{\mathrm{A}, 6}$ : The B-BBEE preferential procurement scores of the considered JSE-listed companies improved over the period 2004-2015.

$\mathbf{H}_{\mathrm{A}, 7}$ : The B-BBEE enterprise development scores of the considered JSE-listed companies improved over the period 2004-2015.

$\mathbf{H}_{\mathbf{A}, 8}$ : The B-BBEE socio-economic development scores of the considered JSE-listed companies improved over the period 2004-2015.

\section{Research design and methodology}

Based on the preceding discussion, it is evident that the 2007 and 2013 Codes differ considerably in terms of the elements included, their weightings and the total number of points available. For the purpose of this article, focus was placed on the Empowerdex scores measured according to the 2007 Codes over the period 2007-2015. The scores for years prior to 2007 were allocated based on the 2004 Codes, which were comparable to the 2007 Codes. Whilst B-BBEE researchers such as Kleynhans and Kruger (2014), Mathura (2009) and Acemoglu et al. (2007) used short timeframes spanning 1-3 years, the authors of this study evaluated B-BBEE compliance of JSE-listed companies over more than a decade by accounting for total and per element B-BBEE scores.

\section{Population and sample}

The population consisted of all companies listed on the JSE's main board and Alternative Exchange over the research period (2004-2015). This time frame was chosen, as the first B-BBEE scores were released in 2004 by Empowerdex, whilst the 2013 Codes were implemented in 2015. As Empowerdex's 2016 list of most empowered companies was based on the 2013 Codes, it was not comparable to the B-BBEE scores obtained under the 2007 Codes.

The sample included listed companies for which Empowerdex made B-BBEE scores available over the period 2004-2015. Kleynhans and Kruger (2014) also applied convenience sampling in their B-BBEE study. Empowerdex annually 
publicly disclosed the B-BBEE scores of approximately 200 JSE-listed companies over the period 2004-2009, based on their willing participation and consent. From 2010 onwards, Empowerdex annually disclosed only the scores of approximately 100 companies. Eight observations for private companies were excluded from the sample. Details on the population and sample are provided in Table 4.

As shown in Table 4, the period under review was divided into two sub-periods called the nascent period and the wider adoption period for the purpose of this study. To address survivorship bias, delisted and suspended companies were included in the sample for the period that they were included in Empowerdex's annual lists. It should be noted that these companies were not necessarily the most empowered companies listed on the JSE, as the total B-BBEE scores of all JSE-listed companies were not available.

Given that the composition of the sample was based on the most empowered companies ranked by Empowerdex for the period under review, an unbalanced panel was considered. Most of the sample companies that were included in the second part of the study period (approximately 100 most empowered companies) werealso included in the first period (approximately 200 most empowered companies). From the total sample of 379 companies, 140 companies were included in both periods. Only the total B-BBEE score per company was publicly released by Empowerdex. The scores per B-BBEE element were sourced from Empowerdex's research department.

\begin{tabular}{lccc} 
TABLE 4: Number of companies included in the sample. & \\
\hline Period & Year & $\begin{array}{c}\text { Number of } \\
\text { companies in the } \\
\text { sample }\end{array}$ & Population (\%)* \\
\hline Nascent & 2004 & 198 & 51 \\
& 2005 & 184 & 49 \\
2006 & 200 & 51 \\
& 2007 & 199 & 48 \\
& 2008 & 188 & 46 \\
Wider adoption & 2009 & 200 & 50 \\
& 2010 & $100 \uparrow$ & 25 \\
& 2011 & 110 & 28 \\
& 2012 & 99 & 26 \\
& 2013 & 82 & 22 \\
2014 & 99 & 26 \\
\hline 2015 & 108 & 28 \\
\hline
\end{tabular}

$\dagger$, The lists of most empowered companies were reduced from approximately 200 to approximately 100; \$, Data were sourced from the World Federation of Exchanges (2016)
Companies were classified in terms of the Industry Classification Benchmark. In line with previous B-BBEE researchers such as Acemoglu et al. (2007), Chipeta and Vokwana (2011), Kleynhans and Kruger (2014) and Mathura (2009), no industries were excluded. There were no companies listed in the utilities industry over the duration of the study period.

\section{Data collection and analysis}

Table 5 shows a description of the B-BBEE scores (in total and per element).

Pertaining to the validity of the B-BBEE scores, the sum of the elements of the B-BBEE scorecard were compared with the total B-BBEE scores that were reported by Empowerdex. There were 30 cases where there were differences between the total B-BBEE scores and the sum of the individual elements. The B-BBEE scorecards for these companies were compared with the actual certificates obtained from the Beagle (2018) database. This database contains the B-BBEE certificates for various private and public companies. In instances where differences were found, the data set was updated to reflect the scores according to the B-BBEE certificate. The total B-BBEE scores that were available on the Bloomberg (2018) database were also compared with those that were obtained from Empowerdex.

As the sample size was larger during the nascent period than the wider adoption period, the sample size of the nascent period (2004-2009) was reduced to include only 100 companies per year, consistent with the sample size of the wider adoption period (2010-2015). The mean B-BBBEE scores were compared for the complete sample and the reduced number of companies as part of the descriptive analysis. This reduction resulted in 1198 observations from 271 companies being used for the inferential analysis. Mixed-model analysis of variance (ANOVA) and Fisher's least significant difference (LSD) tests were conducted to investigate differences in B-BBEE scores (in total and per element) for the 100 most empowered companies. The considered fixed effects factor was year and the random effects factor was JSE ticker code. A restricted maximum likelihood solution with type III decomposition was performed to estimate the variance components of the random effects in the analysis of variance.

TABLE 5: Description of the Broad-Based Black Economic Empowerment scores.

\begin{tabular}{ll}
\hline Score & Description \\
\hline Total B-BBEE & $\begin{array}{l}\text { A company's level of compliance (level one to eight or non-compliant) was based on this score. The total score had a } \\
\text { maximum value of } 100 \text { based on the } 2007 \text { Codes; bonus points could, however, result in a company attaining a score } \\
\text { of more than } 100 .\end{array}$ \\
$\begin{array}{l}\text { Ownership } \\
\text { Management }\end{array}$ & 10 points were available based on the percentage black shareholders. \\
Employment equity & 15 points were available for complying with all the requirements of the Employment Equity Act (No.55 of 1998). \\
Skills development & 15 points were available based on training provided to black workers. \\
Preferential procurement & 20 points were available if a company procured from suppliers with high levels of B-BBEE compliance. \\
Enterprise development & 15 points were available if a company assisted in developing small black-owned enterprises. \\
Socio-economic development & 5 points were available based on the company's corporate social initiatives. \\
\hline
\end{tabular}

B-BBEE, Broad-Based Black Economic Empowerment. 


\section{Findings and discussion}

In the next section, changes in the total B-BBEE scores are discussed followed by trends in the individual elements.

\section{Changes in total Broad-Based Black Economic Empowerment scores}

The trend in the mean total B-BBEE scores is illustrated in Figure 1 by accounting for the total sample and the reduced number of companies (referred to as the top 100, based on their total B-BBEE scores) per year. As explained, Empoweredex provided B-BBEE scores for the 200 most empowered companies from 2004 to 2009, but only published scores for approximately 100 companies between 2010 and 2015 (the wider adoption period). The solid line represents the mean total B-BBEE score of the sample companies per annum, including approximately 200 companies before 2010. To compare the total B-BBEE scores of the 100 most empowered companies ranked by Empowerdex over the entire study period, the dotted line indicates the mean total B-BBEE scores of the so-called top 100 companies from 2004 to 2009.

A mixed-model ANOVA was conducted to determine the significance of the observed trend in total B-BBEE scores (Table 6). The Fisher's LSD test was used to determine whether the mean total B-BBEE scores differed significantly

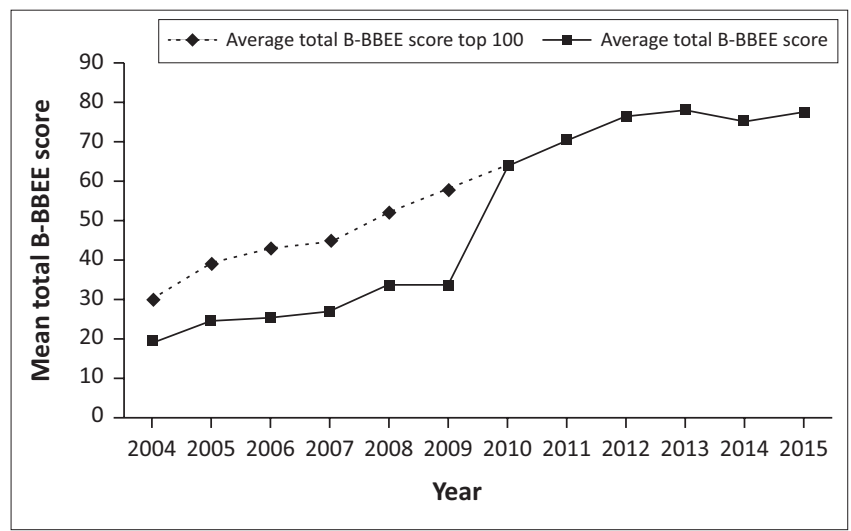

B-BBEE, Broad-Based Black Economic Empowerment.

FIGURE 1: Mean total Broad-Based Black Economic Empowerment score per year. on an annual basis. Only the top 100 companies were used for the period 2004-2009, to make it comparable with the sample size of the wider adoption period (2010-2015). The results are shown in Table 7.

The mean total B-BBEE scores of the considered companies differed significantly over the research period (Table 6). As such, hypothesis $H_{\mathrm{A}, 1}$ could be accepted. Perusal of Table 7 shows that all the annual increases in the mean total B-BBEE scores were statistically significant during the nascent period, except for the annual increase from 2006 to 2007. Four insignificant changes are also noted during the wider adoption period. The insignificant result during the nascent period could be partly ascribed to the release and implementation of the 2007 Codes. Companies may have postponed their B-BBEE efforts until the details of the 2007 Codes became clear. The same argument applies to the release and implementation of the 2013 Codes. The observed changes in the mean total B-BBEE scores were further investigated by accounting for changes in the individual elements.

\section{Changes in the individual Broad-Based Black Economic Empowerment element scores}

The contribution of each element (mean score) to the mean total B-BBEE score is displayed in Figure 2.

It is evident that the mean contribution per element to the total B-BBEE scores varied considerably from 2004 to 2007. Since 2008 onwards, the contribution of each element seemed to increase or decrease in line with the total score per annum. These results could possibly indicate that the sample companies have experienced difficulty to align their B-BBEE practices with the 2004 Codes whilst it was still in draft form. As the Codes were finalised in 2007, the sampled companies seem to have maintained their focus on the elements that they have deemed most important. The increase from

TABLE 6: Mixed-model analysis of variance results for the mean total Broad-Based Black Economic Empowerment scores.

\begin{tabular}{lcccc}
\hline Effect & Numerator $d f$ & Denominator $d f$ & $\boldsymbol{F}$ & $p$ \\
\hline Year & 11 & 1007 & $254.666 *$ & 0.000 \\
\hline$d f$, degrees of freedom. & & &
\end{tabular}

*, Significant at the $1 \%$ level.

TABLE 7: Fisher's least significant difference results for the mean total Broad-Based Black Economic Empowerment scores per annum.

\begin{tabular}{|c|c|c|c|c|c|c|c|c|c|c|c|c|}
\hline Year & 2004 & 2005 & 2006 & 2007 & 2008 & 2009 & 2010 & 2011 & 2012 & 2013 & 2014 & 2015 \\
\hline 2004 & - & $0.000 * *$ & $0.000 * *$ & $0.000 * *$ & $0.000 * *$ & $0.000 * *$ & $0.000 * *$ & $0.000 * *$ & $0.000 * *$ & $0.000 * *$ & $0.000 * *$ & $0.000 * *$ \\
\hline 2005 & - & - & $0.013 *$ & $0.000 * *$ & $0.000 * *$ & $0.000 * *$ & $0.000 * *$ & $0.000 * *$ & $0.000 * *$ & $0.000 * *$ & $0.000 * *$ & $0.000 * *$ \\
\hline 2006 & - & - & - & 0.135 & $0.000 * *$ & $0.000 * *$ & $0.000 * *$ & $0.000 * *$ & $0.000 * *$ & $0.000 * *$ & $0.000 * *$ & $0.000 * *$ \\
\hline 2007 & - & - & - & - & $0.000 * *$ & $0.000 * *$ & $0.000 * *$ & $0.000 * *$ & $0.000 * *$ & $0.000 * *$ & $0.000 * *$ & $0.000 * *$ \\
\hline 2008 & - & - & - & - & - & $0.000 * *$ & $0.000 * *$ & $0.000 * *$ & $0.000 * *$ & $0.000 * *$ & $0.000 * *$ & $0.000 * *$ \\
\hline 2009 & - & - & - & - & - & - & $0.000 * *$ & $0.000 * *$ & $0.000 * *$ & $0.000 * *$ & $0.000 * *$ & $0.000 * *$ \\
\hline 2010 & - & - & - & - & - & - & - & $0.000 * *$ & $0.000 * *$ & $0.000 * *$ & $0.000 * *$ & $0.000 * *$ \\
\hline 2011 & - & - & - & - & - & - & - & - & $0.013 *$ & $0.001 * *$ & $0.017^{*}$ & $0.000 * *$ \\
\hline 2012 & - & - & - & - & - & - & - & - & - & 0.305 & 0.938 & $0.002 * *$ \\
\hline 2013 & - & - & - & - & - & - & - & - & - & - & 0.265 & 0.052 \\
\hline 2014 & - & - & - & - & - & - & - & - & - & - & - & $0.001 * *$ \\
\hline 2015 & - & - & - & - & - & - & - & - & - & - & - & - \\
\hline
\end{tabular}

*, Significant at the $5 \%$ level; **, Significant at the $1 \%$ level. 


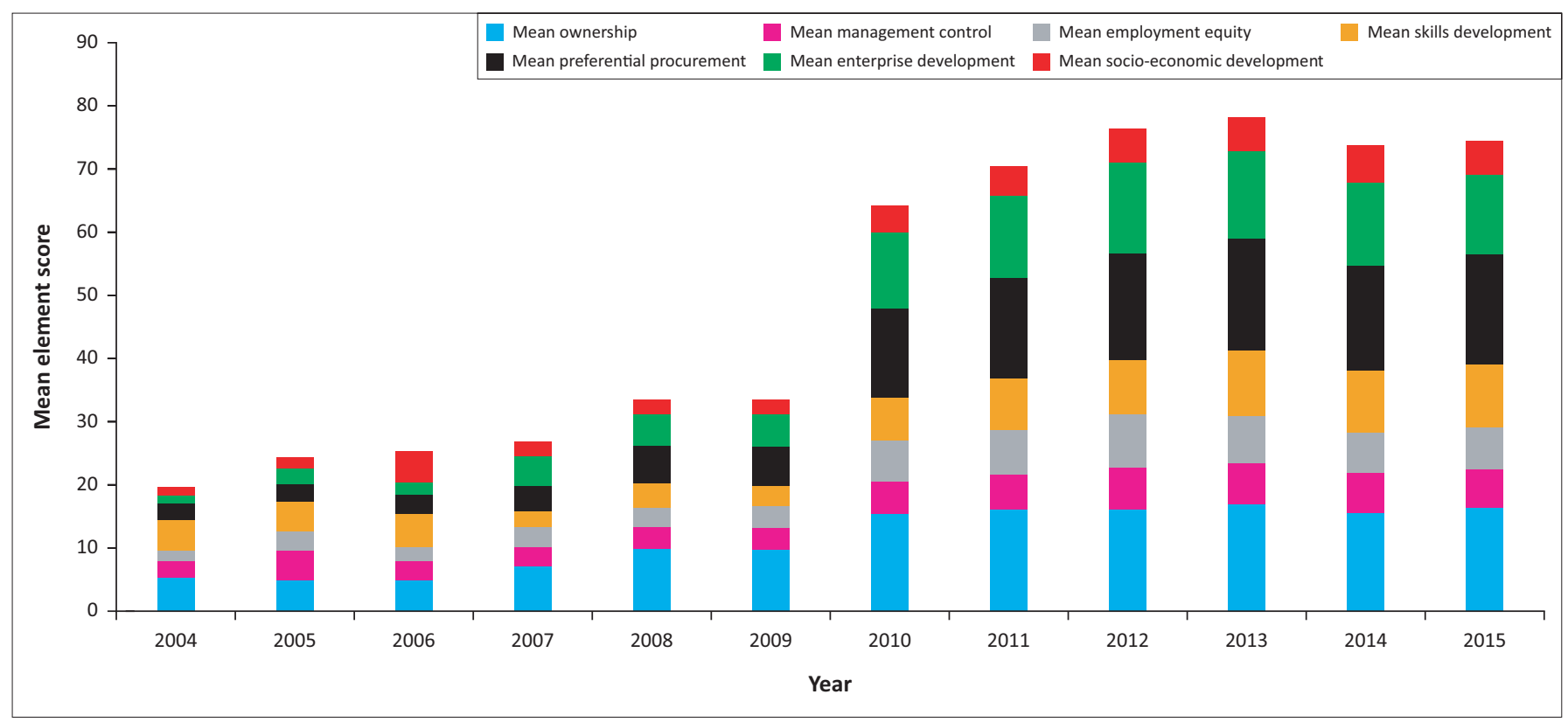

FIGURE 2: Contribution of each element to the mean total Broad-Based Black Economic Empowerment scores.

2009 to 2010 is largely ascribed to the discussed reduction in sample size.

The preferential procurement score was lower than that of the ownership score in 2004, but higher in 2015. It hence seems as if more business owners used preferential procurement to improve their total B-BBEE score, as opposed to transferring the ownership to black shareholders over time. Acemoglu et al. (2007) reported that B-BBEE share transfers took place at discounted share prices. As a result, directors could have been deterred to engage in share transfer transactions and rather focussed on elements that did not have such a substantial impact on shareholder value. Van der Merwe and Ferreira (2014) found that an increase in B-BBEE element scores was negatively associated with changes in share prices.

A higher procurement recognition level contributes to a higher preferential procurement score and, ultimately, to higher total B-BBEE scores for the companies purchasing from these more empowered suppliers. In turn, it could have a positive effect on the preferential procurement score of the customers of the company's customers. It is thus expected that preferential procurement follows an exponential increase until maximum preferential procurement scores are attained.

The scores for skills development from 2013 to 2015 show an increase in line with ownership and preferential procurement. The 2013 Codes do not list employment equity as a separate element but include it as a sub-element of management control. In the 2007 Codes, 10 points were allocated for management control and 15 points for employment equity. The total 25 points allocated for these two aspects in the 2007 Codes was lowered to only 15 points for management control in the 2013 Codes (DTI, 2013). Companies could arguably have anticipated this change and hence placed less emphasis on employment equity.
Enterprise development had a lower average score in 2004 compared with employment equity and skills development. However, enterprise development then surpassed both skills development and employment equity. The considered companies could possibly have invested in enterprise development as a relatively 'easy way' of enhancing their total B-BBEE scores. As such, stakeholders' impressions of the company could be improved. Pertaining to self-promotion (Bolino \& Turnley, 1999), the company might be deemed a competent, empowered entity. Whilst companies are not expected to become directly involved in enterprise development initiatives to which they contribute financially, employment equity requires companies to actively change their employee demographical representation.

Management control displayed a similar pattern to socio-economic development. The average socio-economic development scores increased considerably from 2004 to 2006, after which it stabilised with a steady increase year-onyear. A slight decrease is seen in the socio-economic development score around 2008, which coincides with the global financial crisis. An economic crisis could arguably cause companies to refrain from avoidable expenditure. In the 2007 Codes, the target for socio-economic development was $1 \%$ of net profit after tax (DTI, 2007). The considered companies attempted to maximise socio-economic development scores in the first few years of the nascent period. The moral imperative for socio-economic investment could shed some light on this result. If companies can 'do well' (gain B-BBEE points and possible financial benefits) by 'doing good' (uplifting communities), it is understandable that this element would receive considerable attention. It could also arguably be linked to exemplification, that is, to be seen as morally exemplary based on a company's empowerment initiatives (Bolino \& Turnley, 1999). It should be noted that at least $75 \%$ of beneficiaries should be black, and expenditure on socio-economic development may not 
TABLE 8: Percentage change in the elements scores between 2004 and 2015.

\begin{tabular}{|c|c|c|c|c|c|c|c|c|c|c|c|c|c|}
\hline \multirow[t]{2}{*}{ Variable } & \multicolumn{12}{|c|}{$\%$} & \multirow[t]{2}{*}{ Increase } \\
\hline & 2004 & 2005 & 2006 & 2007 & 2008 & 2009 & 2010 & 2011 & 2012 & 2013 & 2014 & 2015 & \\
\hline Ownership & 37 & 46 & 40 & 52 & 61 & 73 & 77 & 80 & 81 & 85 & 79 & 82 & 1.231 \\
\hline Management control & 36 & 56 & 39 & 43 & 49 & 50 & 52 & 56 & 66 & 64 & 62 & 61 & 0.674 \\
\hline Employment equity & 26 & 47 & 39 & 36 & 34 & 40 & 42 & 48 & 55 & 49 & 43 & 44 & 0.661 \\
\hline Skills development & 36 & 43 & 49 & 33 & 46 & 41 & 47 & 54 & 58 & 70 & 65 & 67 & 0.863 \\
\hline Preferential procurement & 24 & 26 & 30 & 36 & 51 & 58 & 70 & 80 & 85 & 88 & 83 & 87 & 2.634 \\
\hline Enterprise development & 23 & 30 & 38 & 58 & 63 & 71 & 81 & 87 & 96 & 94 & 88 & 84 & 2.648 \\
\hline Socio-economic development & 22 & 31 & 79 & 78 & 73 & 83 & 82 & 90 & 105 & 106 & 117 & 109 & 4.001 \\
\hline
\end{tabular}

be tax deductible if the beneficiary does not provide the donor with a Section 18A tax deductible receipt (DTI, 2007).

Given the slight differences in weightings between the 2004 and the 2007 Codes, the average scores of the elements were expressed as a percentage of the maximum points available for each element. The increase from the 2004 to the 2015 percentages was then expressed as a multiple of the 2004 percentages to reflect increases in the element scores over the duration of the study period (see Table 8).

The percentage scores for the B-BBEE elements more than doubled over the research period. It seemed as if the so-called top 100 companies focus on preferential procurement, enterprise development and socio-economic development. The latter element reflected the largest increase over the research period. The increase in preferential procurement is ascribed to more companies purchasing from B-BBEE compliant companies, thereby increasing their preferential procurement scores, and by implication becoming more B-BBEE compliant.

Mixed-model ANOVA and Fisher's LSD tests were conducted to test hypotheses $\mathrm{H}_{\mathrm{A}, 2}$ to $\mathrm{H}_{\mathrm{A}, 8}$. Statistically significant increases were noted for all elements except during the years that the 2007 and the 2013 Codes were released and implemented. Hypotheses $\mathrm{H}_{\mathrm{A}, 2}$ to $\mathrm{H}_{\mathrm{A}, 8}$ could hence be accepted. The significant increases in compliance scores are encouraging.

The insignificant changes in the total and per element B-BBEE scores noted since 2013 could partly be attributed to poor economic growth, which could have shifted management's attention to financial survival. Expenditure on social initiatives such as B-BBEE could have been decreased. Another explanation is that some of the considered companies could have become 'comfortable' with their B-BBEE compliance levels and hence did not make active attempts to further increase their scores. Alternatively, some of the considered companies that have attained high total scores might have struggled to further increase their B-BBEE scores.

\section{Conclusions and recommendations}

Broad-Based Black Economic Empowerment is the most prominent intervention by the government to address poverty experienced by black people. The application of B-BBEE is driven by the Codes of Good Practice. Since the inception of B-BBEE in 2003, three Codes have been released. This article was based on the 2007 and 2004 Codes. Despite criticism against B-BBEE, the need for economic reform cannot be underestimated. The authors of this study hence investigated whether a sample of listed companies made concerted effort to comply with the B-BBEE Act by accounting for their total and per element B-BBEE scores as provided by Empowerdex for the period 2004-2015. Mixed-model ANOVA and Fisher LSD tests were conducted to investigate the significance of the observed trends. Focus was placed on which elements showed the largest and smallest improvements, respectively.

The mean total B-BBEE score increased considerably over the research period. Whilst the sample companies were, on average, non-compliant in 2004, they achieved level-three B-BBEE scores in 2015. Employment equity showed the smallest increase, whilst socio-economic development reflected the largest increase over the research period. These results could be linked to impression management theory (Bolino \& Turnley, 1999) by postulating that some of the sample companies placed more focus on those elements that are the 'easiest' to comply with. As such, they could have enhanced stakeholders' impressions of them being empowered companies. The mixed-model ANOVA results indicated significant increases over time for the total B-BBEE score and all elements. The Fisher LSD results showed that most of the annual changes were significant, except for the years surrounding the release and implementation of the revised Codes.

In line with a comment made by the South African minister of trade and industry (Phakathi, 2019), policymakers are encouraged to critically reflect on whether B-BBEE has achieved its goal of redressing historical imbalances. Policymakers could investigate other options than preferential procurement to incentivise companies to comply with B-BBEE, such as introducing tax rebates for companies with high B-BBEE scores.

More emphasis should be placed on education, which is deemed critical for economic empowerment. In a time of minimal economic growth, skills development and job creation should be a priority for directors and managers. They play an essential role to ensure a sustainable future for empowerment initiatives in South Africa. Educators furthermore have a significant influence on the future generations of directors and shareholders by enhancing 
awareness of the need for and moral imperative of economic transformation. Entrepreneurial skills could be enhanced and the importance of social justice emphasised by involving students in community upliftment projects. Investment management modules could also include discussions on the moral imperatives of investing.

Shareholders could furthermore request explanations from companies on the imperatives for their B-BBEE initiatives (or the lack thereof). Management should encourage shareholder engagement to clarify concerns and discuss amendments to their empowerment initiatives. The media can furthermore considerably influence the views of shareholders and the broader public on B-BBEE. Whilst the media can play an active role in educating the public on B-BBEE, negative publicity could result in negative sentiment. The media should provide a balanced perspective on B-BBEE to inform local stakeholders and international investors to enable sound decision-making.

\section{Suggestions for future research}

Pertaining to the study's limitations, secondary B-BBEE data were obtained from Empowerdex. During the latter part of the research period, Empowerdex focussed on large listed companies. The identified trends are hence not applicable to all JSE-listed companies. A random sample of JSE-listed companies could be used to repeat this study in future by accounting for their reporting on B-BBEE. A study involving unlisted companies might shed light on B-BBEE trends amongst small entities. The business case for B-BBEE, based on the 2013 Codes, could also be investigated in future.

The extent to which improved compliance scores translate into improved outcomes pertaining to the stated aims of B-BBEE warrants further investigation. Future researchers could conduct interviews with various stakeholders, including black owners of small- and medium-sized enterprises and suppliers and managers of B-BBEE-accredited companies to gauge their views in this regard. Further investigation could also shed more light on why certain elements are favoured by companies.

\section{Acknowledgements}

The authors would like to acknowledge Prof. Martin Kidd for the statistical analysis and Elizma Beets for the language editing.

\section{Competing interests}

The authors declare that they have no financial or personal relationships that may have inappropriately influenced them in writing this research article.

\section{Authors' contributions}

J.A.D., S.V. and N.M.-K. contributed equally to this research article.

\section{Funding information}

This research received no specific grant from any funding agency in the public, commercial or not-for-profit sectors.

\section{Ethical considerations}

This article followed all ethical standards for research without direct contact with human or animal subjects.

\section{Data availability}

Data sharing is not applicable to this article as no new data were created or analysed in this study.

\section{Disclaimer}

The views and opinions expressed in this article are those of the authors and do not necessarily reflect the official policy or position of any affiliated agency of the authors.

\section{References}

Acemoglu, D., Gelb, S., \& Robinson, J.A. (2007). Black Economic Empowerment and economic performance in South Africa. Retrieved from http://www.treasury.gov. $\mathrm{za} /$ publications/other/growth/06-Procurement $\% 20$ and $\% 20$ bee/02-black $\% 20$ economic $\% 20$ empowerment $\% 20$ and $\% 20$ economic $\% 20$ performance $\% 20$ in $\% 20$ so.pdf

Andrews, M. (2008). Is Black Economic Empowerment a South African growth catalyst? (Or could it be...). HKS Faculty Research Working Paper Series, 1-105. Retrieved from http://ssrn.com/abstract=1266797

Beagle. (2018). Beagle scorecard database. Retrieved from https://www. beagledatabase.co.za/search/new

BEE Commission. (2001). BEE Commission report of 2001. Retrieved from https:// www.westerncape.gov.za/text/2004/5/beecomreport.pdf

Bloomberg, L.P. (2018). Research domain. Software and database. New York, NY: Bloomberg.

Bolino, M.C., \& Turnley, W.H. (1999). Measuring impression management in organizations: A scale development based on the Jones and Pittman taxonomy Organizational Research Methods, 2(2), 187-206. https://doi.org/10.1177/ 109442819922005

Chipeta, C., \& Vokwana, T. . . (2011). The impact of Black Economic Empowerment transactions on shareholder wealth and firm profitability: Evidence from the JSE. African Finance Journal, 13(1), 71-91.

Department of Trade and Industry (DTI). (2003). Broad-Based Black Economic Empowerment Act 53 of 2003. Vol. 1. Retrieved from https://www.thedti.gov.za/ economic_empowerment/BEEAct-2003-2004.pdf

Department of Trade and Industry (DTI). (2004). Codes of good practice. Retrieved from https://www.thedti.gov.za/economic_empowerment/docs/bee_archive_ docs/CodeofGoodPractice.pdf

Department of Trade and Industry (DTI). (2007). Codes of good practice. Retrieved from https://www.thedti.gov.za/economic_empowerment/docs/Inside.pdf

Department of Trade and Industry (DTI). (2013). Codes of good practice. Retrieved from https://www.thedti.gov.za/business_regulation/acts/BEE-Amendment_ ACT2013.pdf

De Villiers, C., \& Ferreira, P. (2011). The association between South African listed companies' BEE scores and market performance: An introductory study. Meditari Accountancy Research, 19(1/2), 22-38. https://doi.org/10.1108/102225211 11178619

De Wet, A. (2016). To BEE, or not to BEE? A vital question. Accountancy SA, 1(4), 20.

Empowerdex. (2016). Implication of B-BBEE codes of good practice. Retrieved from http://www.empowerdex.com/ empowerdex/bee-legislation/b-bbee-codes-ofgood-practice

Engdahl, C., \& Hauki, H. (2001). Black Economic Empowerment: An introduction for non-South African businesses. Retrieved from http://reference.sabinet.co.za/ document/EJC118417\nwww.journals.co.za/ej/ejour_ws_sabg.html

Gules, N. (2018). EU wants relaxation of BEE rules before investing in SA, 20 November Retrieved from https://city-press.news24.com/Business/eu-wants-relaxation-ofbee-rules-before-investing-in-sa-20181120

Habib, A., \& Padayachee, V. (2000). Economic policy and power relations in South Africa's transition to democracy. World Development, 28(2), 245-263. https://doi. org/10.1016/S0305-750X(99)00130-8

Hoffman, E. (2008). A wolf in sheep's clothing. Syracuse Journal of International Law and Commerce, 36(87), 87-115. 
Institute of Race Relations (IRR). (2009). South Africa Survey 2009/2010. Retrieved from http://irr.org.za/reports-and-publications/south-africa-survey/south-africafrom http://irr.org.za/rep

Institute of Race Relations (IRR). (2012). BEE should be scrapped, not reformed. Retrieved from http://irr.org.za/reports-and-publications/submissions-onproposed-legislation/policy-submission-bee-should-be-scrapped-not-reformed4th-december-2012

Institute of Race Relations (IRR). (2017). South African survey: Education. Retrieved from http://irr.org.za/reports-and-publications/south-africa-survey/south-africasurvey-2017

Jackson, W., Alessandri, T., \& Black, S. (2005). The price of corporate socia responsibility: The case of Black Economic Empowerment transactions in South Africa. Working Paper Series Federal Reserve Bank of Atlanta. Retrieved from http://ssrn.com/abstract=2482419

Jones, E.E., \& Pittman, T.S. (1982). Toward a general theory of strategic self-presentation. In J. Suls (Ed.), Psychological perspectives on the self (pp. 231-261). Hillsdale, NJ: Lawrence Erlbaum.

Kleynhans, E.P.J., \& Kruger, M.C. (2014). Effect of Black Economic Empowerment on profit and competitiveness of firms in South Africa. Acta Commercii, 14(1), 1-10. https://doi.org/10.4102/ac.v14i1.200

Mathura, A. (2009). The impact of Broad Based Black Economic Empowerment on the financial performance of companies listed on the JSE. Master's thesis. Pretoria: Gordon Institute of Business Science, University of Pretoria.

Mehta, U., \& Ward, M. (2017). The relationship between a Black Economic Empowerment score and shareholder returns in Johannesburg Stock Exchangelisted companies. South African Business Review, 21(1), 85-97.

Morris, C. (2018). The impact of Black Economic Empowerment on business risk Evidence from the South African industrial sector. African Journal of Business and Economic Research, 13(2), 99-120.

Ngwenya, N.X. (2019). Time for a new wave of B-BBEE. Fin24, 25 February. Retrieved from https://www.fin24.com/Opinion/time-for-a-new-wave-of-bee-20190225

Ntim, C.G., \& Soobaroyen, T. (2013). Black Economic Empowerment disclosures by South African listed corporations: The influence of ownership and board characteristics. Journal of Business Ethics, 116(1), 121-138. https://doi.org/ 10.1007/s10551-012-1446-8

Patel, L., \& Graham, L. (2012). How broad-based is Broad-Based Black Economic Empowerment? Development Southern Africa, 29(2), 193-207.
Phakathi, B. (2019). Time to rethink B-BBEE: Ebrahim Patel. Retrieved from https:// www.businesslive.co.za/bd/national/2019-07-04-time-to-rethink-bee-ebrahimpatel/

Ponte, S., Roberts, S., \& Van Sittert, L. (2007). Black Economic Empowerment, business and the state in South Africa. Development and Change, 38(5), 933-955. https:// doi.org/10.1111/j.1467-7660.2007.00440.x

RSA Presidency. (2015). President Zuma to convene BEE advisory council. Retrieved from http://www.thepresidency.gov.za/pebble.asp?relid=19111

Sartorius, K., \& Botha, G. (2008). Black Economic Empowerment ownership initiatives: A Johannesburg Stock Exchange perspective. Development Southern Africa, 25(4), 437-453. https://doi.org/10.1080/03768350802318530

Strydom, B., Christison, A., \& Matias, J. (2009). An empirical investigation of the effect of Black Economic Empowerment transactions on share prices: 1996 to 2006. African Journal of Accounting, Economics, Finance \& Banking Research, 5(5), 67-76.

Tangri, R., \& Southall, R. (2008). The Politics of Black Economic Empowerment in South Africa. Journal of Southern African Studies, 34(3), 699-716. https://doi. South Africa. Journal of Southern
org/10.1080/03057070802295856

The World Bank. (2019). World development indicators. Retrieved from https:// databank.worldbank.org/data/reports. aspx?source $=2 \&$ series $=S I$. POV. GINI\&country=\#

Van der Merwe, C.M., \& Ferreira, P. (2014). The association of the seven elements of the Black Economic Empowerment score and market performance. South African Journal of Economic and Management Sciences, 17(5), 544-556. https://doi. org/10.4102/sajems.v17i5.627

Ward, M., \& Muller, C. (2010). The long-term share price reaction to Black Economic Empowerment announcements on the JSE. Investment Analysts Journal, 39(71), 27-36. https://doi.org/10.1080/10293523.2010.11082517

Werksmans. (2014). Amendments to the B-BBEE Act and the codes explained. Retrieved from http://www.werksmans.com/wpcontent/uploads/2014/02/ 040002WERKSMANS-bbbee-booklet.pdf

Wolmarans, H., \& Sartorius, K. (2009). Corporate social responsibility: The financial impact of Black Economic Empowerment transactions in South Africa. South African Journal of Economic and Management Sciences, 12(2), 180-193. https:// doi.org/10.4102/sajems.v12i2.275

World Federation of Exchanges. (2016). Monthly reports tool. Retrieved from http:// www.world-exchanges.org/home/index.php/statistics/monthly-reports 